Karol Bieniek

Uniwersytet Pedagogiczny im. KEN w Krakowie

\title{
EWOLUCJA POZYCJI USTROJOWEJ WŁADZY WYKONAWCZEJ W REPUBLICE TURCJI
}

\section{Wprowadzenie}

Podstawowym celem artykułu jest analiza ewolucji pozycji ustrojowej władzy wykonawczej w Republice Turcji, od momentu kształtowania się jej państwowości we wczesnych latach dwudziestych ubiegłego stulecia, do chwili obecnej. W toku wywodu omówione zostaną istotne przemiany $\mathrm{w}$ zakresie funkcjonowania władzy wykonawczej mające związek z interwencjami tureckich sił zbrojnych w procesy polityczne, których konsekwencją są kolejne ustawy zasadnicze, odpowiednio z roku 1961 i 1982. Zwrócona zostanie także uwaga na trwający od 2002 roku okres rządów proislamskiej Partii Sprawiedliwości i Rozwoju, której dominacja w systemie politycznym wiąże się z wyraźną tendencją do umacniania struktur władzy wykonawczej.

Pierwsze elementy nowoczesnego, bliskiego modelowi europejskiemu, prawodawstwa pojawiają się u poprzednika nowożytnej Turcji, tj. Imperium Osmańskiego w XIX wieku. Celem wprowadzanych przez poszczególnych sułtanów reform było przekształcenie teokratyczno-feudalnej monarchii w państwo, które mogłoby sprostać wymogom nowoczesności narzuconym przez konkurentów, tj. ówczesne europejskie potęgi. Miały one także stanowić odpowiedź na zmieniające się potrzeby społeczne. Wspomniany okres rozpoczął się w 1808 roku wraz z wydaniem przez sultana Mahmuda II Aktu Przymierza (osm. Sened-i Ittifak). Reformy kontynuował jego następca Abdülmecid I, który w okresie Tanzimatu ${ }^{1}$ wydał Edykt Gülhane (1839) oraz Edykt İslahat (1856). Przywołane dokumenty nie były w oczywisty sposób konstytucjami, nosiły jedynie znamiona, i tak też są określane na gruncie tureckim, dokumentów konstytucyjnych - stanowiły jednostronną deklarację sułtanów oraz potwierdzały uznanie przez nich określonych praw poddanych, takich jak

1 Osmańskie słowo „tanzimat” oznacza reorganizację i odnosi się do okresu reform Imperium, przypadającego na panowanie sułtana Abdülmecida I (1839-1861) i jego następcy Abdülaziza (1861-1876). 
prawo do życia, własności, poszanowanie jednostki, prawo do uczciwego procesu oraz równość wszystkich obywateli osmańskich wobec prawa, bez względu na wyznawaną religię. Co istotne, nie zawierały jakichkolwiek gwarancji, tudzież mechanizmów, pozwalających na wyegzekwowanie przyznanych praw, a jedynie czyniły władcę moralnie odpowiedzialnym za przestrzeganie przyjętych zobowiązań2. Jednocześnie ich oczywistym walorem było to, że po raz pierwszy w historii Imperium Osmańskiego doszło do zerwania z całkowicie absolutystyczną tradycją sprawowania władzy.

Przełomową cezurą w historii tureckiego konstytucjonalizmu był rok 1876, kiedy to pod naciskiem grup reformatorskich sułtan Abdülhamid II wprowadził pierwszą konstytucję (osm. Kanun-i Esasi). Mająca oktrojowany charakter ustawa zasadnicza została przygotowana przez powołany decyzją sułtana komitet, składający się z 28 członków (2 przedstawicieli sił zbrojnych, 16 urzędników oraz 10 ulemów, tj. uczonych religijnych) i stanowiła wyraz kompromisu pomiędzy dążeniami reformatorskimi a kręgami konserwatywnymi skupionymi wokół władcy³. Podstawową nowością było wprowadzenie organu legislacyjnego, tzw. Zgromadzenia Powszechnego (osm. Meclis-i Umumi) składającego się z dwóch izb, tj. Senatu (osm. Heyet-i Ayan), którego członkowie byli dożywotnio mianowani przez sułtana oraz Izby Deputowanych (osm. Heyet-i Mebusan), gdzie przedstawiciele mieli być wybierani w wyniku wyborów pośrednich, a prawem głosu dysponowali jedynie właściciele nieruchomości ${ }^{4}$. Z kolei egzekutywa miała dualny charakter i była dzielona pomiędzy monarchę oraz Radę Ministrów (osm. Heyet-i Vükela). Aczkolwiek przyjęta konstytucja częściowo ograniczała władzę sułtanów, którzy od tej chwili nie mogli już samodzielnie stanowić prawa oraz zmieniać ustawy zasadniczej, to w dalszym ciągu władza wykonawcza pozostawała najważniejszym elementem całego systemu; taki stan rzeczy wynikał z konstytucyjnych prerogatyw monarchy, który posiadał istotne uprawnienia nominacyjne, decydował o polityce zagranicznej, odgrywał kluczową rolę w funkcjonowaniu aparatu sądowniczego oraz, co niezwykle ważne, posiadał prawo rozwiązania Izby Deputowanych w sytuacji, kiedy uznał to za stosowne (art. 7)5. Ponadto kontroli sułtana nad funkcjonowaniem struktur państwowych sprzyjał fakt, że posiadał on tytuł „Najwyższego Kalifa” (art. 4), tj. zwierzchnika muzułmanów oraz tradycja i autorytet władcy, które związane były z długim okresem panowania dynastii osmańskiej. Tym samym przyjęta konstytucja nie ustanawiała klasycznej monarchii parlamentarnej, w której funkcja monarchy

2 E. Özbüdün, Constitutional Law, (w:) T. Ansay, D. Wallace Jr. (red.), Introduction to Turkish Law, Alphen aan den Rijn 2011, s. 19.

3 R. Devereux, The First Ottoman Constitutional Period: a Study of the Midhat Constitution and Parliament, Baltimore 1963, s. 47-48.

4 B. Tanör, Osmanlı-Türk Anayasal Gelişmeleri, İstanbul 2004, s. 139-140.

5 Wszystkie artykuły Konstytucji z roku 1876 za tekstem przedrukowanym w języku tureckim w: A.Ş. Gözbüyük, S. Kili, Türk Anayasa Metinleri 1839-1980, Ankara Üniversitesi Siyasal Bilgiler Fakültesi Yayınları no: 496, Ankara 1982, s. 27-42. 
jest zredukowana do w zasadzie symbolicznego i ceremonialnego wymiaru, a w zdecydowany sposób centrum władzy wykonawczej czyniła panującego i sprawującego realną władzę przedstawiciela rodziny królewskiej. Pomimo tego okazała się ona zbyt postępowa dla sułtana Abdülhamida II, który już w 1878 roku zawiesił jej funkcjonowanie na okres 30 lat. Dopiero w 1908 grupa reformatorów, znana jako „Młodoturcy” (osm./tur. Jön Türkler), zdołała doprowadzić do przywrócenia ustawy zasadniczej. W wyniku wyborów w roku 1909 zwycięstwo przypadło Komitetowi Jedności i Postępu (osm./tur. Ittihat ve Terraki Cemiyeti), który był polityczną emanacją ruchu Młodotureckiego. W 1909 roku Komitet wprowadził zasadnicze zmiany do ustawy zasadniczej: Rada Ministrów stała się politycznie odpowiedzialna przed Izbą Deputowanych oraz ograniczono prawo sułtańskiego weta, które mogło być odrzucone większością dwóch trzecich głosów, wprowadzono instytucję kontrasygnaty dla decyzji sułtana, który nadal miał mianować ministrów, ale na wniosek Wielkiego Wezyra (premiera). Zredukowano także w istotny sposób prawo sułtana do rozwiązywania Zgromadzenia Powszechnego ${ }^{6}$. Tym samym system przyjął formę, która w podstawowym zakresie odpowiadała ówczesnym monarchiom konstytucyjnym zachodniej Europy. Wkrótce jednakże rządy Komitetu przybrały formę dyktatury, a drugi w historii Turcji okres konstytucyjny (tur. Ikinci Meşrutiyet) zakończył się niepowodzeniem - nie zdołano przeprowadzić istotnych dla Imperium reform społecznych, które miały oddalić widmo jego upadku. Klęska poniesiona w I Wojnie Światowej doprowadziła do rozpadu państwa Osmanów i do powstania nowożytnej Republiki Turcji, która już w latach dwudziestych ubiegłego stulecia zaczęła kształtować swój konstytucyjny porządek.

\section{Okres formowania się struktur państwowych oraz samodzielnych rządów kemalistów}

Narzucony Imperium Osmańskiemu traktat z Sèvres (1920 r.) doprowadził do wybuchu Tureckiej Wojny Wyzwoleńczej, na czele której stanął zbuntowany generał armii sułtańskiej Mustafa Kemal, który wraz z późniejszą reformą nazwisk przybrał nazwisko Atatürk. W obliczu uległości działającego w Stambule osmańskiego rządu wobec postanowień traktatu, wezwał on do przeprowadzenia wyborów na kontrolowanych jeszcze przez lojalną wobec niego armię terenach oraz zwołał w Ankarze, mające stanowić przeciwwagę, Tureckie Wielkie Zgromadzenie Narodowe (tur. Türkiye Büykük Millet Meclisi, TBMM). TBMM rozpoczęło działalność w dniu 24 kwietnia 1920 roku, wyposażone było tak we władzę ustawodawczą, jak i wykonawczą, stanowiło więc jednocześnie rząd ${ }^{7}$. W wyniku prowadzonych prac, w 1921 roku utworzono pierwszą turecką konstytucję noszącą nazwę Prawa Zasad-

6 B. Tanör, Osmanlı-Türk..., op. cit., s. 192-197.

7 C. Eroĝul, Anatüzeye Giriş, Ankara 2012, s. 232. 
niczego (tur. Teşkilat-ı Esasiye Kanunu), a sama Turcja weszła w okres dwuwładzy sprowadzającej się do posiadania dwóch rządów (osmańskiego w Stambule oraz narodowowyzwoleńczego w Ankarze) oraz dwóch konstytucji (odpowiednio z 1876 oraz 1921 roku) $)^{8}$.

W zakresie przyjętych rozwiązań ustrojowych władzę wykonawczą oraz ustawodawczą powierzono Wielkiemu Zgromadzeniu Narodowemu (tur. Büyük Millet Meclisi, BMM), które było jedynym reprezentantem narodu (art. 2) $)^{9}$. Zgromadzenie sprawowało władzę wykonawczą za pośrednictwem Komitetu Wykonawczego Ministrów (tur. İcra Vekilleri Heyeti), który był przez nie powoływany i w razie potrzeby dymisjonowany (art. 8). Spośród swoich członków Komitet wybierał Przewodniczącego; oba te organy nie były odpowiednikami premiera i rządu, ale miały w zasadzie kompetencje administracyjne, bazujące na woli Wielkiego Zgromadzenia Narodowego (art. 9). Konstytucja nie ustanawiała urzędu prezydenta, rozumianego jako klasyczna głowa państwa, a jedynie precyzowała, że funkcję tę pełnić będzie przewodniczący BMM, który jednocześnie w tym samym artykule definiowany był ex officio jako Przewodniczący Komitetu Wykonawczego Ministrów (art. 9). Tym samym przyjęte rozwiązania cechowały się dominacją władzy ustawodawczej oraz zbliżały cały system rządów do postaci systemu rządu konwentu. Jednocześnie niezwykle istotne jest postanowienie artykułu 2, które czyniło suwerenem naród turecki - znamionowało to mające wkrótce nastąpić zniesienie wielonarodowej monarchii, utworzenie państwa narodowego oraz przejście do republikańskiej formy rządów.

Utworzeniu Republiki Turcji w dniu 29 października 1923 roku towarzyszyło zupełne przejęcie władzy przez nową elitę, nazywaną odtąd kemalistami. W wyniku przeprowadzonych w 1923 roku wyborów BBM zostało całkowicie zdominowane przez będącą instytucjonalnym narzędziem reform Atatürka Partię Ludowo-Republikańską (tur. Cumhuriyet Halk Partisi, CHP). To właśnie w BBM opracowano Konstytucję Republiki Turcji, która weszła w życie z dniem 20 kwietnia 1924 roku. Zgodnie z nią władza ustawodawcza i wykonawcza powierzona została Tureckiemu Wielkiemu Zgromadzeniu Narodowemu (tur. Türkiye Büykük Millet Meclisi, TBMM) (art. 5) ${ }^{10}$. TBMM miał sprawować władzę wykonawczą za pośrednictwem Prezydenta i Rządu, którzy nie posiadali prawa do rozwiązania parlamentu, a wszystkie ustawy rządowe podlegały jego kontroli. TBMM zachowywało także

W tureckiej literaturze przedmiotu stale obecna jest dyskusja dotycząca uznania Prawa Zasadniczego za pełnoprawną konstytucję. Przeciwnicy zwracają uwagę na jego tymczasowość oraz niedemokratyczny sposób uchwalenia. Z kolei zwolennicy podkreślają jego przełomowość oraz to, że został przyjęty przez grupę, która w ówczesnej sytuacji posiadała realną władzę. Patrz: K. Gözler, Türk Anayasa Hukuku, Bursa 2000, s. 48 i następne. Niejednokrotnie można się także spotkać ze stwierdzeniem, że dokument ten został stworzony w najbardziej demokratyczny sposób w porównaniu do późniejszych konstytucji z lat 1924, 1961, 1982. Patrz: E. Özbüdün, 1921 Anayasası, Anakra 1992, s. 2.

9 Wszystkie artykuły Konstytucji z 1921 roku za jej oryginalnym tekstem dostępnym na: https://www.tbmm.gov.tr/tutanaklar/KANUNLAR_KARARLAR/kanuntbmmc001/kanuntbmmc001/kanuntbmmc00100085.pdf (data dostępu: 12.09.2015 r.).

10 Wszystkie artykuły Konstytucji Republiki Turcji z 1924 za tekstem uwspółcześnionym (sturczonym) w roku 1945 dostępnym na: https://www.tbmm.gov.tr/anayasa/anayasa24.htm (data dostępu: 12.12.2015 r.). 
prawo do zdymisjonowania Rządu (art. 7). Prezydent wybierany był spośród członków TBMM na okres kadencji tegoż, tj. na 4 lata; to on spośród posłów wskazywał kandydata na premiera, który następnie spośród członków TBMM wybierał przyszłych ministrów (art. 44). Po uzyskaniu aprobaty Prezydenta przyszły Premier przedstawiał skład rządu parlamentowi, gdzie musiał uzyskać wotum zaufania. Rząd ponosił odpowiedzialność kolektywną (art. 46). Ponadto Prezydent dzielił z rządem władzę wykonawczą oraz był głową państwa (art. 32). Nie ponosił odpowiedzialności politycznej, a wszystkie jego postanowienia wymagały kontrasygnaty Premiera i właściwego ministra (art. 39). W przyjętej konstrukcji ustrojowej po raz kolejny wyraźnie dostrzegalna jest dominująca pozycja władzy ustawodawczej, aczkolwiek zauważalne są, w większym stopniu niż w Konstytucji z 1921 roku, także elementy klasycznego podziału władzy. Innymi słowy, przy zachowaniu w podstawowym zakresie formy konwentu, wprowadzono do całej struktury pewne elementy właściwe systemom parlamentarno-gabinetowym ${ }^{11}$.

W tym miejscu należy wyraźnie zaznaczyć, że w czasie samodzielnych rządów Atatürka oraz obozu kemalistowskiego postanowienia konstytucji nie pozostawały w zgodzie z praktyką sprawowania władzy. Stanowiąca kulminację długiego procesu walki z absolutyzmem sułtańskim ustawa zasadnicza formalnie promowała władzę ustawodawczą - w praktyce prestiż Atatürka jako twórcy państwa oraz fakt, że w rzeczonym okresie funkcjonował w Turcji system jednopartyjny, w którym jedynym stronnictwem była założona i tożsama ideologicznie z jego poglądami CHP, doprowadziły do sytuacji, w której to właśnie Prezydent stawał się organem odgrywającym wiodącą rolę. C.F. Strong w swoim porównaniu pozycji prezydenta USA i Republiki Turcji zauważa, iż , [...] turecki prezydent dysponuje znacznie większą władzą ponieważ jest jednocześnie liderem organizacji partyjnej mającej większość w Zgromadzeniu, które go wybiera. Tym samym może w zasadzie rozgrywać Zgromadzenie wedle swojego uznania"12. W praktyce taki stan rzeczy implikował nieformalną przewagę egzekutywy, która stała się immanentną cechą tureckiego systemu politycznego w okresie samodzielnych rządów kemalistów ${ }^{13}$. Interesujące jest także, że taka praktyka odpowiadała rządzącym elitom do momentu funkcjonowania systemu jednopartyjnego - szerokie uprawnienia TBMM, brak formalnych ograniczeń władzy ustawodawczej oraz mechanizmów prawnych kontroli konstytucyjności prawa ${ }^{14}$ świetnie sprawdzały się w warunkach monopartii; były jednocześnie optymalnym środowiskiem dla wprowadzania szerokiego programu reform polityczno-społecznych, które na trwałe zmieniły oblicze współczesnej Turcji, zrywając z dziedzictwem Imperium Osmańskiego. Wraz z „odmrożeniem” systemu

\footnotetext{
B. Tanör, Osmanlı-Türk..., op. cit., s. 296.

C.F. Strong, Modern Political Constitutions, London 1952, s. 250.

Po śmierci Atatürka Prezydentem Republiki Turcji i Przewodniczącym CHP został wybrany jego towarzysz z czasów wojennych İsmet İönü, który w całości podzielał poglądy swojego poprzednika. Samodzielne rządy kemalistów trwały do 1946 roku, kiedy to w wyniku wyborów do TBMM dostała się opozycyjna Partia Demokratyczna. 
partyjnego oraz zwycięstwem w 1950 roku opozycyjnej Partii Demokratycznej (tur. Demokrat Partisi, DP) przyjęty system stał się, w warunkach większościowego pojmowania demokracji, instrumentem wykorzystanym do walki z opozycyjną, kemalistowską CHP. W 1960 roku Tureckie Siły Zbrojne, postrzegające siebie jako twórców państwa oraz obrońców wartości kemalizmu, przeprowadziły wojskowy zamach stanu, którego konsekwencją było wprowadzenie nowej ustawy zasadniczej w 1961 roku $^{15}$.

\section{Funkcjonowanie władzy wykonawczej w konstytucjach Republiki Turcji z lat 1961 i 1982}

Przyjęta w 1961 roku Konstytucja Republiki Turcji powstała pod wpływem Tureckich Sił Zbrojnych i w wyraźny sposób nosi znamiona inżynierii społecznej ${ }^{16}$. Podstawowym celem stało się zredukowanie dominującej pozycji władzy ustawodawczej, tj. TBMM - to co nie stanowiło problemu dla rządzącej elity w okresie monopartii, stało się dla niej zagrożeniem w momencie przejścia do opozycji i doprowadziło, w uproszczeniu ${ }^{17}$, do zamachu stanu. Wraz z adaptacją nowego systemu rządów zdecydowano się zapobiec takiej sytuacji, w której to Parlament będzie odgrywał dominującą rolę w systemie ${ }^{18}$. Paradoksalnie było to przyczyną tego, że przyjęte w 1961 roku rozwiązania ustrojowe cechują się niskim stopniem oryginalności, kształtując system parlamentarno-gabinetowy. Kluczowym jest, że Konstytucja z 1961 roku powstała pod naciskiem wojskowych, których cechowała tak nieufność wobec cywilnych polityków, jak i do organów władzy państwowej kreowanych w wyniku wyborów powszechnych. Władzę tych organów starano się ograniczyć za pomocą autonomicznych instytucji, takich jak chociażby powołany do życia Sąd Konstytucyjny (tur. Anayasa Mahkemesi) ${ }^{19}$. Ustrojodawca dążył jednocześnie do wprowadzenia i realizacji zasady trójpodziału władzy, ale do systemu zostały włączone elementy mające gwarantować polityczną kuratelę armii nad procesami politycznymi. Władza ustawodawcza należała do TBMM, które miało się składać od tej pory z dwóch izb, niższej - tj. Zgromadzenia Narodowego (tur. Millet Meclisi) oraz wyższej, tj. Senatu (tur. Cumhuriyet Senatosu) (art. 63) ${ }^{20}$. Wojskowi zagwaran-

Przedłożony artykuł, z racji swojej problematyki, nie omawia w szczegółowy sposób bezpośrednich przyczyn zamachów stanu z 1960 i 1980 roku oraz procesu powstawania kolejnych ustaw zasadniczych. Należy jednocześnie zauważyć, że obie konstytucje nie powstały w sposób demokratyczny, a zostały wypracowane na wyraźne polecenie Tureckich Sił Zbrojnych i stanowiły emanację ich dążenia do odgórnego kształtowania tureckiej rzeczywistości politycznej. Więcej na ten temat patrz: K. Bieniek, System partyjny Republiki Turcji w latach 1950-2011, Warszawa 2013.

16 R. Aybay, Some Contemporary Constitutional Problems in Turkey, „Bulletin (British Society for Middle Eastern Studies)" 1977, vol. 4, nr. 1, s. 21.

Patrz przypis nr 15.

Ibidem, s. 23.

R. Devereux, Turkey`s New Constitutional Court, „SAIS Review” 1963, nr 7, s. 19.

Wszystkie artykuły Konstytucji Republiki Turcji z 1961 r. za: https://www.tbmm.gov.tr/anayasa/anayasa61.htm (data dostępu: 10.11.2015 r.). 
towali sobie przewagę w 165-osobowej izbie wyższej, z urzędu mieli do niej wejść oficerowie, którzy dokonali zamachu stanu oraz (w przyszłości) byli prezydenci. Ponadto Prezydent miał dokonywać nominacji 15 osób (art. 70). Pochodząca w całości z wyborów powszechnych izba niższa miała liczyć 450 deputowanych (art. 67). W zakresie funkcjonowania władzy wykonawczej najbardziej istotną właściwością rozwiązań ustrojowych przyjętych w 1961 roku jest to, że funkcje władcze zostały przydzielone odrębnym organom, legislatywie i egzekutywie, ale ta ostatnia, realizowana przez Prezydenta i Radę Ministrów, nie wywodziła się już z parlamentu, co stanowiło nową jakość wobec postanowień Konstytucji z 1924 roku. Prezydent posiadał szereg kompetencji nominacyjnych o symbolicznym charakterze (art. 97), nie ponosił odpowiedzialności politycznej; wszystkie decyzje podlegały obowiązkowi kontrasygnaty Premiera oraz właściwego Ministra (art. 98). Prezydent powoływał i odwoływał Ministrów na wniosek Premiera (art. 102) oraz mógł rozwiązać Zgromadzenie Narodowe jedynie w szczególnych okolicznościach, na wniosek Premiera (art. 108). Podstawowym organem władzy wykonawczej była Rada Ministrów obradująca pod przewodnictwem Premiera, który w przeciwieństwie do swoich ministrów, musiał być członkiem parlamentu (art. 102). Członkowie rządu podlegali zasadzie odpowiedzialności kolegialnej, ponadto poszczególni ministrowie odpowiadali za swoje obowiązki (art. 105).

Podsumowując należy zauważyć, iż Konstytucja z roku 1961 stanowiła emanację woli wojskowych elit do kształtowania systemu politycznego Turcji. W celu zapobieżenia koncentracji władzy w organie legislacyjnym dokonano separacji władz, a całość systemu rządów była bliska systemom parlamentarno-gabinetowym.

Pozycja ustrojowa władzy wykonawczej znacząco zmieniła się dopiero w roku 1982, kiedy to wprowadzono nową ustawę zasadniczą. Podobnie jak jej poprzedniczka z 1961 roku, także ona była wynikiem wojskowego zamachu stanu, którego dokonano w 1980 roku $^{21}$. Można stwierdzić, że w swoim dążeniu do kształtowania form ustrojowych Turcji wojskowi posunęli się jeszcze dalej niż 20 lat wcześniej. W 1980 roku zdelegalizowali wszystkie partie polityczne oraz stworzyli konstytucję, która miała na trwałe zapewnić im kontrolę nad tureckim życiem politycznym - wyrazem takiego stanu rzeczy było ukształtowanie systemu określanego na gruncie tureckiego konstytucjonalizmu jako „osłabiona forma parlamentaryzmu”22, gdzie rola i znaczenie elementu egzekutywy, jakim jest Prezydent, są daleko bardziej idące niż w klasycznych systemach rządów. W istocie, nowa ustawa zasadnicza wyposażała Prezydenta w szereg kompetencji wobec legislatywy, egzekutywy oraz władzy sądowniczej. Precyzyjnie są one określone w artykule 104 Konstytucji Republiki Turcji z 1982 roku, który jednocześnie jest jej najdłuższą częścią. W odniesieniu do władzy ustawodawczej Prezydent Republiki Turcji: może zarządzić zwołanie Turec-

22 E. Özbüdün, Contemporary Turkish Politics, Challenges to Democratic Consolidation, Boulder 2000, s. 59-60. 
kiego Wielkiego Zgromadzenia Narodowego (TBMM) ${ }^{23}$, pełni istotną rolę w procesie ustawodawczym dysponując prawem weta, poddania ustawy pod referendum lub odesłania jej do Sądu Konstytucyjnego celem zweryfikowania jej konstytucyjności oraz, w określonych przepisami prawa warunkach, rozpisuje wybory ${ }^{24}$. Uprawnienia wykonawcze Prezydenta sprowadzają się do: powołania Premiera i przyjęcia jego rezygnacji, powoływania i odwoływania poszczególnych ministrów na wniosek Premiera, zwoływania i przewodniczenia obradom Rady Ministrów, kiedy tylko uzna to za stosowne, przyjmowania i akredytowania przedstawicieli dyplomatycznych, ratyfikowania traktatów międzynarodowych, reprezentowania Naczelnego Dowódcy Tureckich Sił Zbrojnych w TBMM, zarządzania mobilizacji Tureckich Sił Zbrojnych i powoływania ich Szefa Sztabu Generalnego, przewodniczenia obradom Rady Bezpieczeństwa Narodowego, wprowadzania stanu wyjątkowego i stanu wojny, wydawania dekretów, powoływania członków Rady Szkolnictwa Wyższego oraz rektorów uniwersytetów (art. 104). W zakresie władzy sądowniczej Prezydent posiada szerokie uprawienia nominacyjne w odniesieniu do praktycznie wszystkich kluczowych szczebli tureckiego sądownictwa (art. 104). W kontekście silnej władzy Prezydenta istotną jest kwestia jego politycznej odpowiedzialności - zgodnie z konstytucją wszystkie dekrety głowy państwa wymagają kontrasygnaty Premiera i stosownego ministra, którzy ponoszą za nie polityczną odpowiedzialność (art. 105). Jednocześnie ten sam artykuł wzmacnia władzę Prezydenta dopuszczając odstępstwo od tej zasady w sytuacji, gdy jest to określone przepisami konstytucji lub innych ustaw (dotyczy to chociażby dekretu o rozpisaniu referendum). Dla samodzielnych decyzji i dekretów Prezydenta ustrojodawca nie przewidział mechanizmów kontroli ze strony władzy sądowniczej, tudzież postępowania przed Sądem Konstytucyjnym (art. 105).

Wprowadzona w 1982 roku ustawa zasadnicza obowiązuje w Turcji do dnia dzisiejszego, aczkolwiek poddawana była wielu poprawkom konstytucyjnym. Jej zasadniczą cechą jest to, że znacząco została wzmocniona władza wykonawcza poprzez poszerzenie kompetencji Prezydenta, który stał się istotnym graczem w systemie politycznym ${ }^{25}$. Bez wątpienia było to celowym zabiegiem wojskowego establishmentu, zmierzającego do rozciągnięcia politycznej kurateli nad Turcją ${ }^{26}$.

Konstytucja z 1982 roku przywraca jednoizbowy Parlament.

Wszystkie artykuły Konstytucji Republiki Turcji z 1982 r. za: https://www.tbmm.gov.tr/anayasa/anayasa_2011.pdf (data dostępu: 12.12.2015 r.).

Niniejszy artykuł z racji ograniczonej objętości nie analizuje całego systemu rządów przyjętego w Konstytucji z 1982 roku. Zachował on wiele istotnych elementów właściwych dla struktur parlamentarno-gabinetowych, ale opisane wzmocnienie roli Prezydenta pozwala na wysnucie wniosku o znaczącym wzmocnieniu egzekutywy. Przeprowadzone w 1982 roku referendum konstytucyjne miało skrajnie niedemokratyczny charakter oraz wykluczało jakąkolwiek debatę. Głosujący opowiadał się jednocześnie za przyjęciem Konstytucji oraz objęciem urzędu Prezydenta przez przywódcę wojskowego zamachu stanu gen. Kenana Evrena, który został wybrany na siedmioletnią kadencję. 


\section{Podsumowanie}

W toku kształtowania państwowości oraz rozwoju systemu politycznego współczesnej Republiki Turcji widoczne są przemiany w zakresie roli odgrywanej przez władzę wykonawczą w kolejnych okresach. Ustawy zasadnicze z lat 1921 i 1924 w sposób formalny zakładały dominację legislatywy, aczkolwiek rzeczywistość polityczna okresu samodzielnej władzy kemalistów skłania ku refleksji o nieformalnej przewadze egzekutywy. Z kolei Konstytucja z 1961 roku, będąca wynikiem zamachu stanu, miała na celu tak poszerzenie znacząco katalogu praw i wolności, jak i stabilizację procesów politycznych mających podlegać logice parlamentarno-gabinetowego systemu rządów. Pomimo istnienia formalnych mechanizmów rywalizacja polityczna wymknęla się zamierzeniom establishmentu wojskowego, a polaryzacja polityczna i radykalny konflikt stały się stałą cechą tureckiego życia politycznego końca lat siedemdziesiątych ubiegłego wieku. Ustawa zasadnicza z 1982 roku, będąca konsekwencją zamachu stanu przeprowadzonego 2 lata wcześniej, czyniła organ egzekutywy, tj. Prezydenta, strażnikiem całego systemu, wyposażając go w realne kompetencje pozwalające na ingerencję i kształtowanie procesów politycznych.

W okresie przypadających od 2002 roku samodzielnych rządów proislamskiej Partii Sprawiedliwości i Rozwoju (tur. Adalet ve Kalkınma Partisi, AKP) widocznym stała się także tendencja do wzmacniania statusu Prezydenta, która ma związek z osobistymi politycznym aspiracjami R. T. Erdoĝana, twórcy partii i do 2014 roku premiera Turcji - wykorzystując kryzys konstytucyjny politycy AKP zdołali w 2007 roku wprowadzić poprawkę konstytucyjną, która ograniczała kadencję prezydenta do 5 lat oraz zakładała, że będzie on wybierany w wyborach powszechnych ${ }^{27}$. Jednocześnie konstytucyjne uprawnienia tego organu nie uległy zasadniczej modyfikacji, a na gruncie tureckiego konstytucjonalizmu panuje zgoda, że całość systemu znacząco zbliżyła się do postaci semiprezydenckiej ${ }^{28}$.

Niejako osobną kwestią jest dążenie R.T. Erdoĝana do wprowadzenia systemu prezydenckiego. Dyskusja na temat nowej ustawy zasadniczej stale funkcjonuje $\mathrm{w}$ dyskursie politycznym Turcji, ponieważ wszystkie istotne siły polityczne zgadzają się, że Konstytucja z 1982 roku została uchwalona niedemokratycznie i pomimo wielu poprawek, nie spełnia wymogów właściwych dla nowoczesnego państwa prawnego. Prace nad nowym dokumentem nabrały przyspieszenia w roku 2011, kiedy to po wygranych przez AKP wyborach parlamentarnych powołano, przy udziale wszystkich partii politycznych, Komisję Pojednania Konstytucyjnego. Nie zdołała ona jednakże wypracować spójnego dokumentu, a rozbieżności pomiędzy obozem kemalistowskiej CHP a proislamskiej AKP okazały się nie do pogodzenia. Komisja zaprzestała prac w 2013 roku. Jednocześnie R. T. Erdoĝan stale podkre-

\footnotetext{
27 W wyniku wyborów powszechnych przeprowadzonych w 2014 roku Prezydentem Republiki Turcji został R.T. Erdoĝan.

28 E. Teziç, Anayasa Hukuku, İstanbul 2012, s. 523.
} 
Śla konieczność przyjęcia nowej ustawy zasadniczej, która wprowadzałaby w Turcji system prezydencki. W chwili obecnej kwestia ta jest przedmiotem istotnego sporu politycznego. Z racji swojej tematyki niniejszy artykuł nie podejmuje się analizy zasadności adaptacji w Republice Turcji rzeczonego sytemu rządów.

\section{BIBLIOGRAFIA}

Aybay Rona. 1977. „Some Contemporary Constitutional Problems in Turkey”. Bulletin (British Society for Middle Eastern Studies) Vol. 4, nr. 1:21-27.

Bieniek Karol. 2013. System partyjny Republiki Turcji w latach 1950-2011. Warszawa: Elipsa.

Devereux Robert. 1963. The First Ottoman Constitutional Period: a Study of the Midhat Constitution and Parliament. Baltimore: The Johns Hopkins University Press.

Devereux Robert. 1963. „Turkey`s New Constitutional Court”. SAIS Review nr. 7: 19-28.

Eroĝul Cem. 2012. Anatüzeye Giriş. Ankara: İmaj Yayınevi.

Gözbüyük Abullah Şeref, Kili Suna. 1982. Türk Anayasa Metinleri 1839-1980. Ankara: Ankara Üniversitesi Siyasal Bilgiler Fakültesi Yayınları.

Gözler Kemal. 2000. Türk Anayasa Hukuku. Bursa: Ekin Kitapevi Yayınları.

Özbüdün Ergun. 1992. 1921 Anayasası. Anakra: ATAM Yayınları.

Özbüdün Ergun. 2011. Constitutional Law. W: Introduction to Turkish Law, 19-50. Alphen aan den Rijn, Kluwer Law International BV.

Özbüdün Ergun. 2000. Contemporary Turkish Politics, Challenges to Democratic Consolidation. Boulder: Lynne Rienner Publishers.

Strong Charles Frederick. 1952. Modern Political Constitutions. London: Sidgwick \& Jackson.

Tanör Bülent. 2004. Osmanl1-Türk Anayasal Gelişmeleri. İstanbul: Yapı Kredi Yayınları.

Teziç Erdoĝan. 2012. Anayasa Hukuku. İstanbul: Beta Yayınevi. 


\section{THE EVOLUTION OF EXECUTIVE POWER IN THE REPUBLIC OF TURKEY}

In broad perspective, this paper analyses the role of the executive power in the entire state structure of the Republic of Turkey, i.e. from the creation of modern Turkish statehood in the early 1920 s up to the recent period. Similarly analysed are the important measures towards executive power that have been implemented, mainly due to interventions of the Turkish military in civilian politics. The paper also focuses attention on the Justice and Development Party`s era in Turkish politics, since its domination in the political system combines with a strong tendency to strength the executive branch.

Keywords: The Republic of Turkey, executive power, constitutions of Turkey, president

Słowa kluczowe: Republika Turcji, władza wykonawcza, konstytucje Turcji, prezydent 